\title{
Case for diagnosis. Linear Darier's disease*
}

\author{
Fernanda Del Pintor Bidoia ${ }^{1}$, Bruna Martini Massanares ${ }^{1}$, Eduardo Vinicius Mendes Roncada ${ }^{1}$, \\ Luiza Vasconcelos Schaefer ${ }^{1}$
}

DOI: http:/ / dx.doi.org/10.1590/abd1806-4841.20187893

\section{CASE REPORT}

A 60-year-old man presented for evaluation of recurrent keratotic brownish papules and plaques linearly distributed on the abdomen, following the Blaschko's lines (Figure 1). The papules were mildly pruritic and had developed over the last 6 years. He reported that, in the last years, he had consulted several doctors and had been treated repeatedly for recurrent herpes zoster with acyclovir, with no improvement.

Biopsy of the plaque revealed hyperkeratosis, hypergranulosis, acanthosis, and suprabasal acantholysis associated with corps ronds, besides inflammatory infiltrate in the papillary layer of the dermis (Figure 2). Linear Darier's disease was then diagnosed.

The patient was treated with topical clobetasol $0.05 \%$ and acitretin $25 \mathrm{mg}$ / per day for 2 months, with good response (Figure 3).

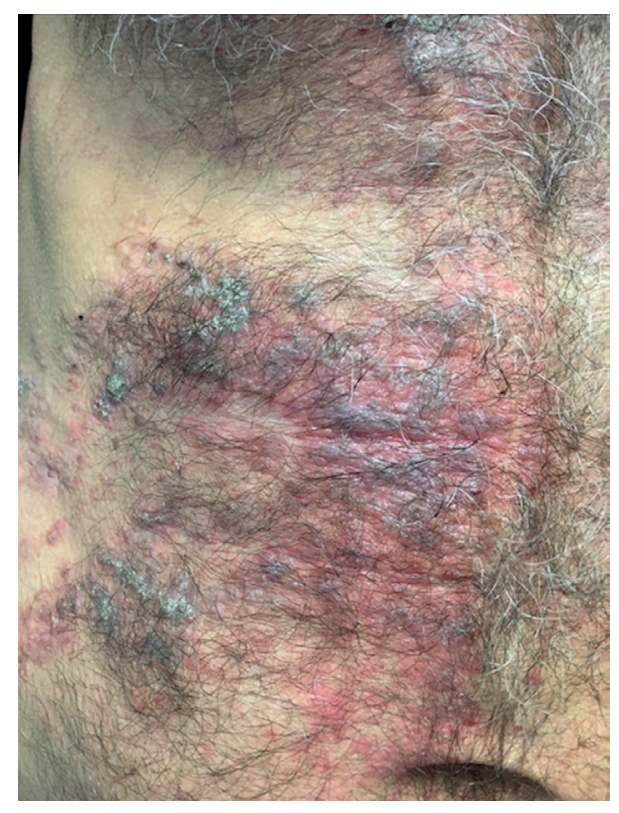

Figure 1: Abdominal lesions. Brownish keratotic papules and plaques linearly distributed on the abdomen

Received 21 November 2017.

Accepted 01 February 2018.

* Work conducted at Hospital Regional de Presidente Prudente, Universidade do Oeste Paulista, Presidente Prudente (SP), Brazil.

Financial support: None.

Conflict of interest: None.

1 Dermatology Service, Hospital Regional de Presidente Prudente, Universidade do Oeste Paulista, Presidente Prudente (SP), Brazil.

Mailing AdDREss:

Fernanda Del Pintor Bidoia

E-mail: fer_bidoia@hotmail.com

(C)2018 by Anais Brasileiros de Dermatologia 

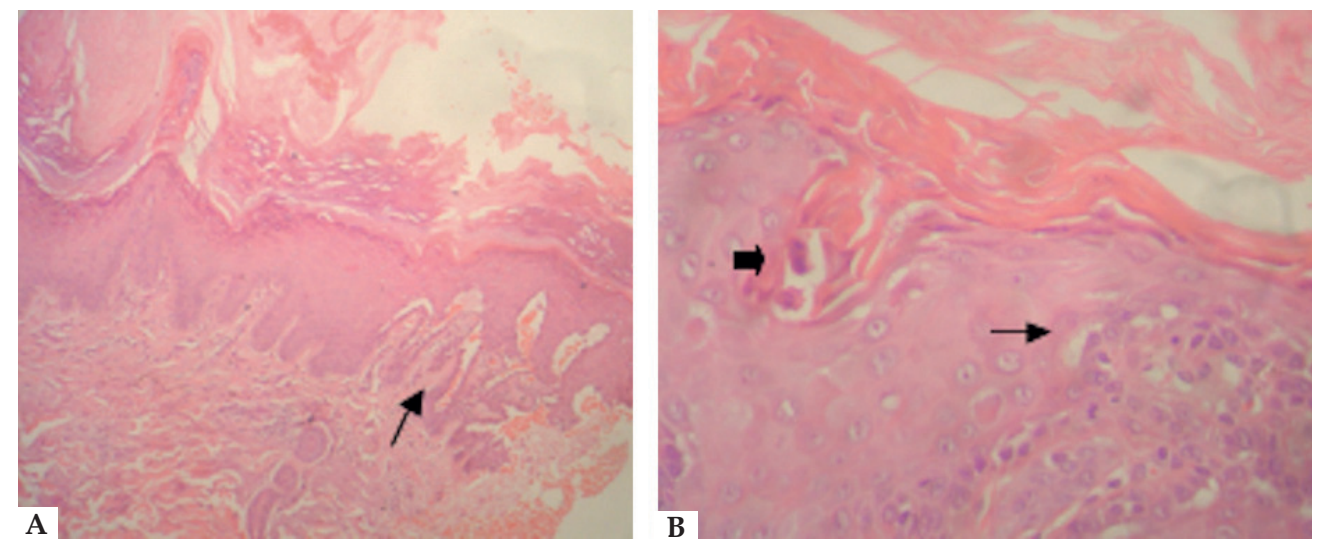

Figure 2: Histopathological study.

A - Hyperkeratosis, hypergranulosis, and irregular acanthosis with suprabasal acantholysis (arrow) (Hematoxylin \& eosin, original magnification $\times 100$ ).

B - Grains in the stratum corneum (thick arrow) and acantholysis (thin arrow)

(Hematoxylin \& eosin, original magnification $\times 400$ )

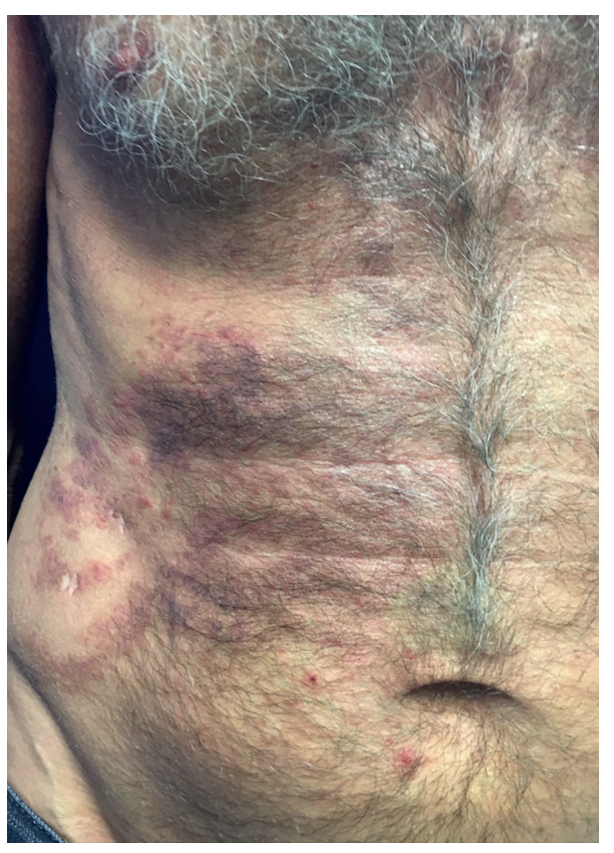

Figure 3: Appearance of the lesions after 2 months of treatment with topical clobetasol $0.05 \%$ and oral acitretin $25 \mathrm{mg} /$ per day, with reduction of erythema and hyperkeratosis

\section{DISCUSSION}

Linear or zosteriform Darier's disease was first described in 1906 and is still a rare disorder, with few cases reported in the literature. It presents as reddish-brown, pruritic, keratotic papules distributed linearly along the Blaschko's lines.
The disease has been associated with abnormalities in the ATP2A2 gene, identified as an underlying cause, since the lead to insufficient function of the calcium-ATPase pump in the endoplas$\mathrm{mic} /$ sarcoplasmic reticulum, consequently causing premature keratinization and acantholysis, due to impact on the adhesion between the keratinocytes. ${ }^{1-3}$ Some authors report that UV light can be an exacerbating factor. ${ }^{4}$

Linear Darier's disease tends to appear during the third or fourth decade of life, with no gender predilection. The most frequently affected area is the trunk. The surrounging skin is absolutely normal; some authors believe that this results from postzygotic mutation and heterozygosity for the disease, with the development of point mutations. It is also believed that in the presence of gonadal mosaicism, the mutation can be transmitted to the patient's offspring, but it is extremely rare in the linear form. ${ }^{5}$ Differential diagnosis includes Grover's disease, epidermal dyskeratotic nevus, and lichen striatus.

Histological examination is indispensable to confirm the diagnosis, and the disorder is indistinguishable from typical Darier's disease in the seborrheic area: hyperkeratosis, papillomatosis, acanthosis, besides dyskeratotic keratinocytes leading to acantholysis, corps ronds, and corp grains. ${ }^{6}$ According to the literature, tretinoin, salicylic acid, and corticosteroids can be used as topical treatments. Oral therapy can include retinoids such as acitretin. Pulsed dye laser and topical adapalene have also been reported as possible alternatives. Our patient responded well to topical corticoid and oral acitretin and is still in follow-up at our department. ${ }^{7-9}$ 
Abstract: We present a different and rare manifestation of Darier's disease, namely linear Darier's disease. Only a few cases have been described in the literature. The case report is a male patient, 60 years old, presenting brown to red papules and plaques with hyperkeratosis distributed on the abdomen, following Blaschko's lines, with 6 years' evolution. It was a difficult diagnosis until the dermatological workup and biopsy.

Keywords: Calcium-transporting ATPases; Darier's disease; Medication adherence; Mosaicism

\section{REFERENCES}

1. Lavorato FG, Azulay-Abulafia L, Ramos V, Obadia DL, Rocha DS, Souza VF. Case for diagnosis. Type 1 linear Darier's disease. An Bras Dermatol. 2013;88:656-8.

2. Sakuntabhai A, Dhitavat J, Burge S, Hovnanian A. Mosaicism for ATP2A2 Mutations Causes Segmental Darier's Disease. J Invest Dermatol. 2000;115:1144-7.

3. Ren V, Champion RW, Boyd AS, Powers JG. Linear, pruritic red to brown papules on the left chest. Dermatol Online J. 2014;20:15.

4. Itin PH, Büchner SA, Happle R. Segmental Manifestation of Darier Disease: What Is the Genetic Background in Type 1 and Type 2 Mosaic Phenotypes? Dermatology. 2000;200:254-7.

5. Barfield RL, Barrett KR, Moon CM, David-Bajar K. Pruritic Linear Papules on a 75-Year-Old Woman: A Case of Localized Darier-White Disease. Cutis. 2002;70:225-8.
6. Rapini RP. Dermatopatologia prática. 2 ed. Rio de Janeiro: Elsevier; 2013.

7. Gilaberte M, Puig L, Vidal D, Alomar A. Acantholytic dyskeratotic naevi following Blaschko's lines: a mosaic form of Darier's disease. J Eur Acad Dermatol Venereol. 2003;17:196-9.

8. O'Malley MP, Haake A, Goldsmith L, Berg D. Localized Darier disease. Implications for genetic studies. Arch Dermatol. 1997;133:1134-8.

9. Casals M, Campoy A, Aspiolea F, Carrasco MA, Camps A. Successful treatment of linear Darier's disease with topical adapalene. J Eur Acad Dermatol Venereol. 2009;23:237-8

\footnotetext{
AUTHORS'CONTRIBUTIONS

Fernanda Del Pintor Bidoia $\quad$ (iD) ORCID 0000-0002-2514-951X

Design and planning of the study, Preparation and writing of the manuscript, Intellectual participation in propaedeutic and/or therapeutic conduct of studied cases

Bruna Martini Massanares $\quad$ (iD) ORCID 0000-0002-6327-4530

Design and planning of the study, Preparation and writing of the manuscript
}

\author{
Eduardo Vinicius Mendes Roncada $\quad$ (iD) ORCID 0000-0002-2149-2388 \\ Approval of the final version of the manuscript, Effective participation in research orien- \\ tation, Critical review of the literature \\ Luiza Vasconcelos Schaefer \\ (iD) ORCID 0000-0001-9837-9714 \\ Critical review of the literature, Critical review of the manuscript
}

How to cite this article: Bidoia FP, Massanares BM, Roncada EVM, Schaefer LV. Case for diagnosis. Linear Darier's disease. An Bras Dermatol. 2018;93(5):749-51. 